\title{
Effect of Family History on Clinical and Pathological Characteristics of Breast Cancer: a Hospital-Based Study in Egypt
}

Taghreed M Farahat ${ }^{1}$, Hala M Shaheen ${ }^{1}$, Nora A Khali1 ${ }^{*}$, Naser M Abd El Bary $^{2}$, Yassmin H Hussin ${ }^{3}$.

${ }^{1}$ Family medicine department, faculty of medicine, Menoufia University

${ }^{2}$ Clinical oncology department faculty of medicine, Menoufia University

${ }^{3}$ Family medicine department, Faculty of Medicine, Zagazig University

Corresponding author:

Nora A khalil

Lecturer at Family Medicine Department, Faculty of Medicine, Menoufia University.

Tel. No: 00201002089093

Fax No.:0020482235679

E_mail Adress: nora_abdelhady@yahoo.com

Running title: Familial and sporadic breast cancer 


\title{
Effect of Family History on Clinical and Pathological Characteristics of Breast Cancer: a Hospital-Based Study in Egypt
}

Taghreed M Farahat ${ }^{1}$, Hala M Shaheen ${ }^{1}$, Nora A Khalil ${ }^{1 *}$, Naser M Abd El Bary ${ }^{2}$, Yassmin H Hussin ${ }^{3}$.

${ }^{1}$ Family medicine department, faculty of medicine, Menoufia University

${ }^{2}$ Clinical oncology department faculty of medicine, Menoufia University

${ }^{3}$ Family medicine department, Faculty of Medicine, Zagazig University

\begin{abstract}
:
Background: Breast cancer is the most common female malignancy. The family history of breast cancer increases the risk of the disease.

Objectives: To assess the frequency of familial breast cancer among breast cancer patients attending oncology outpatient clinics in Menoufia University Hospital and to compare the clinical and pathological characteristics of familial and sporadic breast cancer. Methods: The study was conducted on 150 women with familial or sporadic breast cancer who were attending oncology outpatient clinics, Menoufia University Hospital for follow up or receiving treatment. The participants were interviewed by predesigned questionnaire to assess risk factors for breast cancer. Data on different characteristics of the tumors were gathered from patients' medical records. Results: Familial cases represented $18.7 \%$ of studied breast cancer patients. The age of onset seems to be younger in familial breast cancers $(\mathrm{P}=0.008)$. Percentage of familial breast cancer cases was significantly more prevalent among premenopausal females $(\mathrm{P}=0.007)$. Percentage of studied cases who breastfed their babies, had bilateral breast cancer, had triple negative breast cancer and with larger tumor size (T4) was significantly more prevalent among familial than sporadic breast cancer cases $(\mathrm{P}=0.023,0.006,0.000,0.000$ respectively). About $63 \%$ of sporadic cases were among hormonal contraceptive users versus $43 \%$ in familial group $(\mathrm{P}=0.040)$. There was no significant difference between familial and sporadic groups regarding histological type was observed. Conclusion: Familial cases represented $18.7 \%$ of studied breast cancer patients. Familial breast cancer seems to affect premenopausal young women and tends to present at the larger size, bilateral and triple negative tumors.
\end{abstract}

Key words: breast cancer, family history, tumor characteristics.

\section{Introduction:}

Breast cancer (BC) is the commonest female malignancy accounting for $22.9 \%$ and $37.7 \%$ of all female cancers all over the world and in Egypt, respectively ${ }^{(1)}$ Breast cancer in Egypt seems to have a bad prognosis with $29 \%$ mortality. It is the most common cause of death among women with cancer worldwide. ${ }^{(2)}$ The family history of breast cancer increases the risk of the disease, and the risk depends on the number of relatives, type of the tumor and age at diagnosis among relatives who have had breast cancer. $^{(3)}$ 
* Corresponding author. E-mail address: nora_abdelhady@yahoo.com

Genetic predisposition, such as mutations in BRCA1 and BRCA2 genes, probably contribute to increasing risk of subsequent breast cancers, particularly in women diagnosed at a young age. ${ }^{(4)}$ Many studies documented that familial breast cancer has many specific clinical features compared to sporadic cases. Breast cancer cases with positive family history tend to present at younger age, bilateral breast cancer, advanced tumor stage, lymph node involvement and negative hormone receptors with a bad prognosis. ${ }^{(5)}$

However, other studies found no significant differences between familial and sporadic breast cancer regarding age at diagnosis, histological features, and tumor stage and hormone receptors status. ${ }^{(6)}$

The family history of breast cancer is considered as a significant risk factor in the etiology of this disease. Based on the above-mentioned view, there was a need to conduct the current study to assess the frequency of familial breast cancer among breast cancer patients attending oncology outpatient clinics in Menoufia University Hospital and to compare the clinical and pathological characteristics of familial and sporadic breast cancer among the studied participants.

\section{Methods:}

This study was a cross-section comparative study conducted in oncology outpatient clinics of Menoufia university hospital, Menoufia Governorate, Egypt. It was carried out throughout the period from February 2016 to September 2016. The sample size was calculated based on the familial breast cancer prevalence $5-10 \%{ }^{(7)}$ and a number of registered breast cancer patients in Oncology outpatient clinics, Menoufia University Hospital which was 1500 ( obtained from Oncology outpatient clinics records, 2015). Using online Raosoft sample size calculator, at 95\% confidence level and 5\% margin of error, the sample was estimated to be 115 and increased to 148 to avoid data loss.

The study included previously diagnosed breast cancer patients attending outpatient oncology clinic for follow up or receiving treatment. Male patients were 
excluded. An interview was conducted with each participants using a pre-designed validated questionnaire to obtain information about different clinical characteristics related to breast cancer including age at diagnosis, age at menarche, parity, breastfeeding history, menopause status, and contraceptive history.

A detailed medical record review was done to obtain data about clinical and pathological characteristics of breast cancer among the studied cases (tumor localization, histological type, tumor size, lymph node involvement, pathological stage and hormone receptor status). The studied cases were divided into two groups: Familial Breast Cancer (FBC) including patients with positive family history $(\mathrm{n}=28)$ and Sporadic Breast Cancer (SBC) group including sporadic patients without any family history of breast cancer $(n=120)$. The family history was considered as positive when the patient had one or more relative with breast cancer within three generations.

\section{Ethical approval:}

The study was approved by the ethical committee of the faculty of medicine, Menoufia University. An official permission letter was obtained from the authorities and directed to local administrators in Oncology outpatient clinics in Menoufia University Hospital. Written consent was taken from each participant in the study after simple clarification of the study objectives and methodology.

\section{Statistical Analysis:}

Data were analyzed using Statistical Package of Social sciences (SPSS) software (Statistical Package for the Sociable Sciences, version 20, SPSS Inc. Chicago, IL, USA). Data was expressed through:

Qualitative data were expressed as number and percentage and analyzed by using Chisquared test $\left(\mathrm{X}^{2}\right)$ to detect the relation between different qualitative variable. Quantitative data were expressed as mean \pm SD and analyzed by using Student t-test for comparison of two independent normally distributed quantitative variables.

\section{Results:}

This study found that patients with familial breast cancer represent $19 \%$ of the studied breast cancer patients (Figure 1). Among cases with FBC; 75\% of them have the positive family history in first degree relatives. About $57 \%$ of relatives with BC was diagnosed at $40-50$ years old (Table1). The age of onset appears to be younger in FBC 
patients with a mean age of 45.8 years compared to 50.8 years in the SBC patients $(\mathrm{P}=$ 0.008). Also, FBCs are more likely to be presented in premenopausal period $78.6 \%(\mathrm{P}=$ 0.007). However, there was no statistical difference between the two groups as regards mean age at menarche and parity (Table 2).

There was a statistically significant difference between FBC group and SBC group as regard breastfeeding as $65 \%$ of the SBC had negative breastfeeding history versus $42.9 \%$ in the FBC group (P-value 0.03). There was a statistically significant difference between FBC group and SBC group regarding hormonal contraceptive use as $64.2 \%$ of sporadic patients are among hormonal contraceptive users versus $43 \%$ in familial group $(\mathrm{P}=0.038)$. (Table 2$)$

Regarding tumor localization; the current study showed that bilateral breast cancer was significantly more prevalent among familial than sporadic breast cancer cases (P=value 0.006) (Table 2).

As regards histological features of the tumor, invasive ductal carcinoma (IDC) was identified as the predominant histological type in both groups $(89.3 \%$ and $90 \%$ respectively). There was a statistically significant difference between FBC group and SBC group regarding tumor size as T4 tumors were observed in patients of FBC group with the frequency of $25 \%$ versus $2.5 \%$ in patients of SBC group $(\mathrm{P}=0.001)$. (Table 3) The results regarding hormonal status had showed that the expression of estrogen receptor (ER), progesterone receptors (PR) and human epidermal growth factor 2 receptors (Her2) showed no significant difference between FBC and SBC groups. However, triple negative $\mathrm{BC}$ is significantly more prevalent among familial than sporadic breast cancer cases $(\mathrm{P}=0.001)$. (Table 3$)$

\section{Discussion:}

Carcinoma of the breast is considered the most commonly diagnosed cancer among females and it is the second leading cause of cancer-related deaths among them. ${ }^{(8,9)}$ One of the major risk factors for breast cancer is the family history of the disease. $^{(10)}$ Out of 150 studied breast cancer cases, $19 \%$ had a positive family history of the disease. This is in concordance with a study conducted in Morocco by Tazzite et al. ${ }^{(11)}$ who found that the frequency of breast cancer family history among their studied cases 
was $18.4 \%$. However, Destounis et al. ${ }^{(12)}$ found that out of 388 studied breast cancer patients $39 \%$ reported a positive family history of the disease.

In the current study, more than $90 \%$ of relatives of FBC patients were diagnosed above the age of 40 years old, this is similar to finding of Brewer et al ${ }^{(3)}$ study which found that more than $85 \%$ of affected relatives were diagnosed after the age of 45 years old. The present study found statistically significant difference between Familial and Sporadic breast cancer patients as regard mean age at diagnosis; Familial breast cancer women were diagnosed at an early age. This is in agreement with results of Tazzite et al ${ }^{(11)}$ and Molino et al study ${ }^{(13)}$ which found a lower mean age in patients with the positive family history of breast cancer.

Moreover, a study in Egypt ${ }^{(\mathbf{1 4})}$ stated that family history of breast cancer has been observed in a series of young Egyptian women diagnosed with breast cancer. About 12\% of their cancer patients aged 35 years old and younger. Also, the present study reported a significant difference between familial and sporadic breast cancer patients regarding menopausal status as a percentage of premenopausal women were higher among familial cases.

Similarly, Jiang et al study (15) noted a significantly higher frequency of premenopausal women among the FBC patients and they recommended that FBC patients may benefit from screening and surveillance for early detection of the disease. Breast cancer is hormone-dependent cancer, and the effect of hormonal factors -such as breastfeeding and hormonal contraception- on the familial risk of this disease has been previously studied. ${ }^{(16)}$

This study found statistically significant difference between both groups regarding breastfeeding; as a higher percentage of the sporadic group had negative breastfeeding history. This is supported by Lambertini et al. study ${ }^{(17)}$ which confirmed the protective effect of ever breastfeeding against hormone receptor-negative breast cancer, which is more common in younger women. Also, Toss et al ${ }^{(18)}$ found a protective effect of breastfeeding only in triple negative breast cancer which represent only $15 \%$ of breast cancer cases and this explains the results of the present study which found that breastfeeding had no protective effect against familial breast cancer. 
The present study reported that hormonal contraceptive use was significantly more prevalent among patients with sporadic breast cancer. This is in agreement with a study conducted by Work et $\mathrm{al}^{(19)}$ who reported that hormonal contraceptive use was significantly higher among sporadic than familial breast cancer patients, while in contrast to Tazzite et al ${ }^{(11)}$ who reported that there is no significant difference between familial and sporadic cases as regarding hormonal contraceptive use.

This study showed no significant difference between familial and sporadic breast cancer cases as regard age at menarche, age at first delivery and parity. The same finding was reported by results of several studies..$^{(17,18,20)}$ Horn et al ${ }^{(21)}$ explained this finding by the fact that familial breast cancer is more frequently hormone receptor negative tumors, while age at menarche, age at first delivery and parity seems to modify mostly the incidence of hormone receptor-positive tumors.

In the current study; ductal carcinoma is the most common histological form in both groups. This comes in parallel to results of Saxena et al study ${ }^{(22)}$ in New Delhi which revealed that Infiltrating duct carcinoma was the commonest form among familial and sporadic breast cancer patients. However, in previous publications, ${ }^{23,24)}$ invasive lobular carcinoma was believed to be associated with family history of breast cancer.

As regard tumor size; the present study showed a significantly higher percentage of T4 tumors in patients with positive family history. This disagrees with Arpino et al ${ }^{(25)}$ who found no significant relation between tumor size and familial or sporadic breast cancer. Also, this study reported that bilateral breast cancer was significantly more frequently in the FBC group. This is inconsistent with Verkooijen et al ${ }^{(26)}$ and Margolin et al ${ }^{(6)}$ who stated that bilateral breast cancer is more likely to be presented in patients with positive family history than those with negative family history.

In the current study, triple negative breast cancer was significantly more prevalent among familial breast cancer cases. These findings were in agreement with a study conducted in Egypt, ${ }^{(27)}$ which reported that triple negative breast cancer is commonly overexpressed in cases with positive family history compared to cases with negative family history. Also, Aysola et al ${ }^{(28)}$ stated that triple negative breast cancer accounts for $15 \%$ of all breast cancer cases, with worst prognoses in young African American women. 
Conclusion: Familial cases represented 19\% of studied breast cancer patients. Familial breast cancer seems to affect premenopausal young women and tends to present at a larger size, bilateral and triple negative tumors. Findings of this study may be helpful to identify familial breast cancer and allow developing a careful follow-up for susceptible patients.

\section{Declaration:}

There was no conflict of interest and there were no funding agencies.

\section{References}

1. The National Cancer Registry Program of Egypt. Reports and Statistics: Aswan, Damietta \& El-Minia. Reports.aspx. 2017.Available at www.dpa.gov.eg/?page_id=317. Accessed on May 2017.

2. Ferlay J, Soerjomataram I, Dikshit R, Eser S, Mathers C, Rebelo M. Cancer incidence and mortality worldwide: sources, methods and major patterns in GLOBOCAN 2012. Int J Cancer 2015; 136(5): E359-86

3. Brewer HR, Jones ME, Schoemaker MJ, Ashworth A, Swerdlow AJ. Family history and risk of breast cancer: an analysis accounting for family structure. Breast Cancer Res Treat 2017; 10: 4017-4325.

4. Schottenfeld D, Beebe-Dimmer J. Multiple Primary Cancers, Cancer Prevention and Early Detection. $2^{\text {nd }}$ Edition. New York: Oxford University Press, 2006: 1269-1280.

5. Triantafyllidou O, Vlachos IS, Apostolou P, Konstantopoulou I, Grivas A. Epidemiological and clinicopathological characteristics of BRCA-positive and BRCA-negative breast cancer patients in Greece. JBUON 2015; 20(4): 978-984.

6. Margolin S, Johansson H, Rutqvist LE, Lindblom A, Fornander T. Family history, and impact on clinical presentation and prognosis, in a population-based breast cancer cohort from the Stockholm County. Fam Cancer 2006; 5(4): 309-321.

7. Schwartz G.F., Hughes K.S., Lynch H.T. Proceedings of the international consensus conference on breast cancer risk, genetics, \& risk management. Cancer 2007; 113(10):2627-2637.

8. Lindsey A, Torre MS, Freddie B, Rebecca L. Global cancer statistics. CA Cancer J Clin 2015; 65:87-108. 
9. Wahba H.A., El-Hadaad H.A. Current approaches in the treatment of triple negative breast cancer. Cancer Biol Med 2015; 12(2):106-116.

10. Al-Amri FA, Saeedi MY, Al-Tahan FM, Ali AM, Alomary SA, Arafa M, et al . Breast cancer correlates in a cohort of breast screening program participants in Riyadh, KSA. Journal of the Egyptian National Cancer Institute 2015; 27:77-82.

11. Tazzite A, Jouhadi H, Saiss K, Benider A, Nadifi S. Relationship between family history of breast cancer and clinic-pathological features in Moroccan patients. Ethiop J Health Sci 2013; 23(2): 150-157.

12. Destounis SV, Arieno AL, Morgan RC, Cavanaugh D, Posy J, Seifert PJ, et al. Comparison of Breast Cancers Diagnosed in Screening Patients in Their 40s With and Without Family History of Breast Cancer in a Community Outpatient Facility. AJR 2014; 202: 928 - 929.

13. Molino A, Giovannini M, Pedersini R. Correlations between family history and cancer characteristics in 2256 breast cancer patients. Br J Cancer 2004; 91(1):96-98.

14. Farouk O, Ebrahim MA, senbel A, emarah Z, Abozeed W, seisa MO. Breast cancer characteristics in very young Egyptian women $\leq 35$ years. Breast Cancer: Targets and Therapy 2016; 8:53 - 58.

15. Jiang X, Castelao JE, Chavez-Uribe E. Family history and breast cancer hormone receptor status in a Spanish cohort. PLoS One 2012; 7(1): e29459.

16. Andrieu N, Prevost T, Rohan TE. Variation in the interaction between familial and reproductive factors on the risk of breast cancer according to age, menopausal status, and degree of familiality. Int J Epidemiol 2000; 29(2): 214-223.

17. Lambertini M, Santoro L, Del Mastro L, Nguyen B, Livraghi L, Ugolini D. Reproductive behaviors and risk of developing breast cancer according to tumor subtype: A systematic review and meta-analysis of epidemiological studies. Cancer Treat Rev 2016; 49:65-76.

18. Toss A, Grandi G, Cagnacci A, Marcheselli L, Pavesi S. The impact of reproductive life on breast cancer risk in women with family history or BRCA mutation. Oncotarget 2017; 8 (6): 9144-9154. 
19. Work ME, John EM, Andrulis IL. Oral Contraceptive Use and Parity Associations with Uncommon Breast Cancer Histologies in the Breast Cancer Family Registry: the Role of Family History. Cancer Epidemiol Biomarkers Prev 2011; 20: 715.

20. Ritte R, Tikk K, Lukanova A, Tjønneland A, Olsen A, Overvad K. Reproductive factors and risk of hormone receptor positive and negative breast cancer: a cohort study. BMC Cancer 2013; 13:584.

21. Horn J, Opdahl S, Engstrøm MJ, Romundstad PR, Tretli S, Haugen OA. Reproductive history and the risk of molecular breast cancer subtypes in a prospective study of Norwegian women. Cancer Causes Control 2014; 25:881-889.

22. Saxena S, Rekhi B, Bansal A, Bagga A, Chintamani, Murthy NS. Clinicomorphological patterns of breast cancer including family history in a New Delhi hospital, India--a cross-sectional study. World J Surg Oncol. 2005; 13:3-67.

23. Allen-Brady K, Camp NJ, Ward JH, Cannon-Albright LA. Lobular breast cancer: excess familiarity observed in the Utah Population Database. Int J Cancer 2005; 117(4): 655-661.

24. Li CI, Daling JR, Malone KE. Relationship between established breast cancer risk factors and risk of seven different histologic types of invasive breast cancer. Cancer Epidemiol Biomarkers Prev 2006; 15(5): 946-954.

25. Arpino G, Pensabene M, Condello C, Ruocco R, Cerillo I, Lauria R, et al. Tumor characteristics and prognosis in familial breast cancer. BMC cancer 2016 29; 16(1):924.

26. Verkooijen HM, Chappuis P.O., Rapiti E. Impact of familial risk factors on management and survival of early-onset breast cancer: a population-based study. $\mathrm{Br} \mathbf{J}$ Cancer 2006; 94: 231-238.

27. Bogan D, Meile L, El Bastawisy A, Yousef HF, Zekri AN. The role of BRCA1-IRIS in the development and progression of triple negative breast cancers in Egypt: possible link to disease early lesion. BMC Cancer 2017; 17:329-338.

28. Aysola K., Desai A., Welch C., Xu J., Qin Y., Reddy V., Matthews R. Triple Negative Breast Cancer - An Overview. Hereditary Genet. 2013 (Suppl 2). pii: 001 


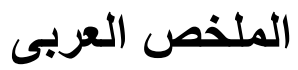

\section{تأثير التاريخ العائلي على الخصائص الاكلينيكيه والمرضيه لسرطان الثذي: دراسه

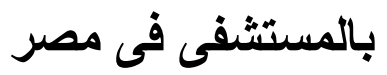

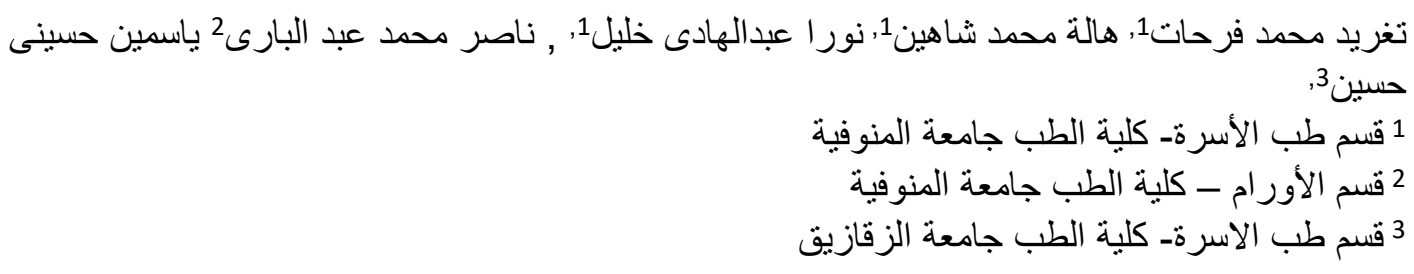

الخلفية: ان سرطان الثدي هو اكثر الامراض الخبيثة شيو عا بين الإناث. التاريخ العائلي للإصابة بسرطان الثدي يزيد من خطر التعرض لهذا المرض. الأهداف: وتهدف هذه الدراسه الى تقييم الخصائص المختلفة لسرطان الثدي في المرضى الذين يعانون من سرطان الثدي العائلي و من لم يكن لايهم تاريخ عائلى للمرض بين المترددين على العيادات الخارجية

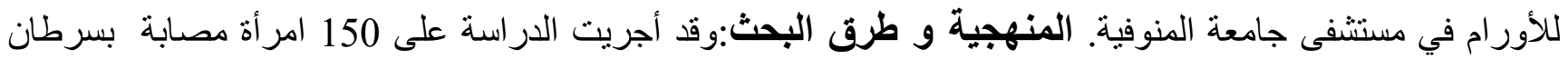

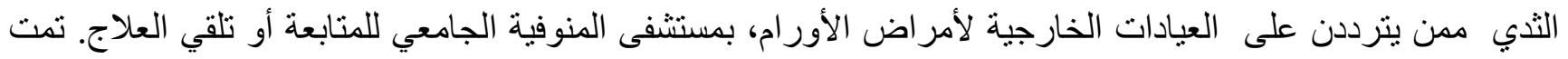

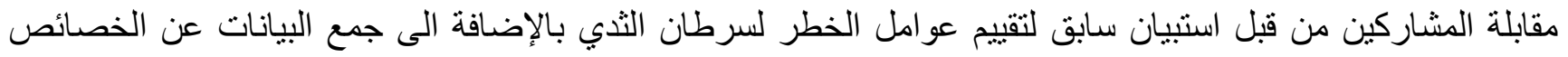
المختلفة لهذه الأورام من السجلات الطبية للمرضى. النتائج:وقد اظهرت النتائج ان الحالات ذات التاريخ الإيجابى للمرض تمثل 18.7٪ من مرضى سرطان الثدي فى العينة الدختارة. و تبين أن الإصابة بسرطان الثدي العائلي يبدأ فى سن مبكر

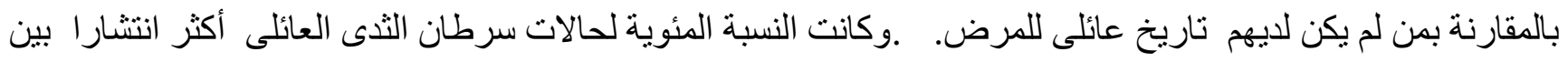

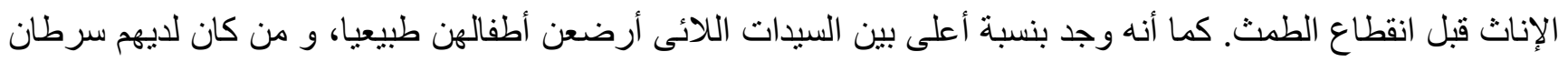

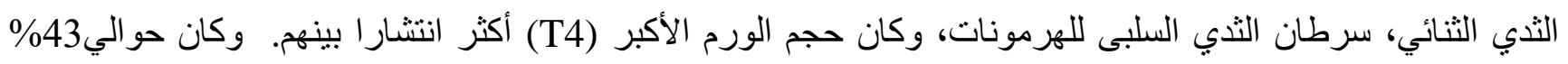

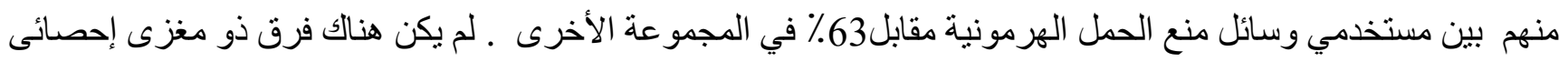

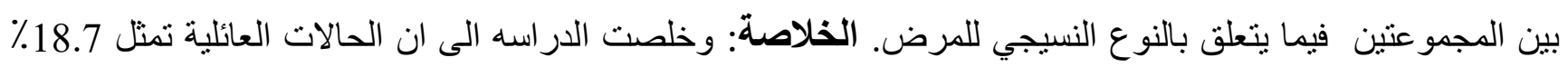

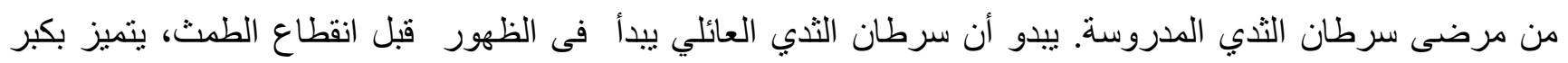

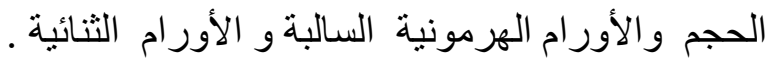




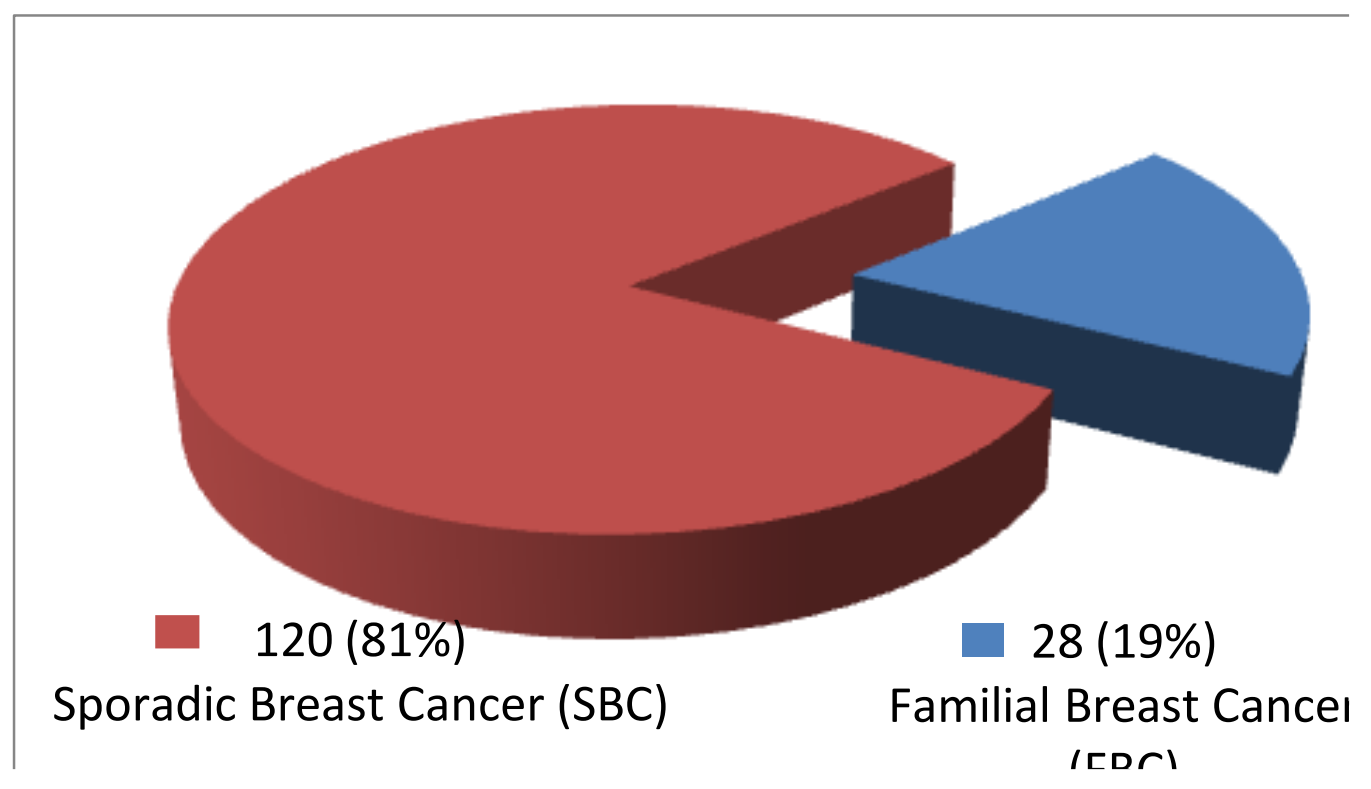

Figure (1): Distribution of breast cancer patients according to breast cancer family history.

Table (1): Breast Cancer history among relatives of patients with familial breast cancer

\begin{tabular}{|c|c|c|}
\hline Breast cancer history in relatives & $\mathbf{N}(28)$ & $\%$ \\
\hline $\begin{array}{l}\text { Degree of relativity } \\
\text { - First degree relatives } \\
\text { - Second degree relatives } \\
\text { - First and second degree relatives }\end{array}$ & $\begin{array}{c}21 \\
3 \\
4\end{array}$ & $\begin{array}{c}75 \\
10.7 \\
14.3\end{array}$ \\
\hline $\begin{aligned} \text { Age at diagnosis in relatives } \\
\text { - } 30-40 \\
\text { - } 40-50 \\
\text { - } \quad>50\end{aligned}$ & $\begin{array}{c}2 \\
16 \\
10\end{array}$ & $\begin{array}{c}7.1 \\
57.2 \\
35.7\end{array}$ \\
\hline
\end{tabular}


Table (2): Comparison between familial and sporadic breast cancer regarding clinical characteristics related to breast cancer

\begin{tabular}{|c|c|c|c|c|c|c|c|c|}
\hline \multirow{3}{*}{ Clinical characteristics } & \multicolumn{2}{|c|}{ FBC $(\mathrm{N}=28)$} & \multicolumn{2}{|c|}{$\operatorname{SBC}(\mathrm{N}=120)$} & \multicolumn{2}{|c|}{$\begin{array}{c}\text { Total } \\
(\mathrm{N}=148)\end{array}$} & \multirow[t]{2}{*}{\begin{tabular}{|l} 
Student \\
t-test
\end{tabular}} & \multirow{3}{*}{$\mathbf{P}$} \\
\hline & \multicolumn{2}{|c|}{ FBC } & \multicolumn{2}{|c|}{ SBC } & \multicolumn{2}{|c|}{ Total } & & \\
\hline & $N=28$ & $\%$ & $\mathrm{~N}=120$ & $\%$ & $\mathrm{~N}=\mathbf{1 4 8}$ & $\%$ & $\mathbf{X}^{2}$ & \\
\hline $\begin{aligned} & \text { Parity } \\
& \text { - Nulliparious } \\
& \text { - Parious }\end{aligned}$ & $\begin{array}{l}6 \\
22\end{array}$ & $\begin{array}{l}21.4 \\
78.6\end{array}$ & $\begin{array}{l}18 \\
102\end{array}$ & $\begin{array}{l}15 \\
85\end{array}$ & $\begin{array}{l}24 \\
124\end{array}$ & $\begin{array}{l}16.2 \\
83.8\end{array}$ & $0.691^{*}$ & 0.406 \\
\hline $\begin{array}{c}\text { Breast feeding } \\
\text { - Yes } \\
\text { - No }\end{array}$ & $\begin{array}{l}16 \\
12\end{array}$ & $\begin{array}{l}57.1 \\
42.9\end{array}$ & $\begin{array}{l}42 \\
78\end{array}$ & $\begin{array}{l}35 \\
65\end{array}$ & $\begin{array}{l}58 \\
90\end{array}$ & $\begin{array}{l}39.2 \\
60.8\end{array}$ & 4.67 & $0.030 * *$ \\
\hline $\begin{array}{l}\text { Menopausal status } \\
\text { - Pre-menopause } \\
\text { - } \text { Post-menopause }\end{array}$ & $\begin{array}{l}22 \\
6\end{array}$ & $\begin{array}{l}78.6 \\
21.4\end{array}$ & $\begin{array}{l}56 \\
64\end{array}$ & $\begin{array}{l}46.7 \\
53.3\end{array}$ & $\begin{array}{l}78 \\
70\end{array}$ & $\begin{array}{l}52.7 \\
47.3\end{array}$ & 9.27 & $0.002 * *$ \\
\hline $\begin{array}{l}\text { Hormonal contraceptive use } \\
\text { - Yes } \\
\text { - No }\end{array}$ & $\begin{array}{l}12 \\
16\end{array}$ & $\begin{array}{l}42.9 \\
57.1\end{array}$ & $\begin{array}{l}77 \\
43\end{array}$ & $\begin{array}{l}64.2 \\
35.8\end{array}$ & $\begin{array}{l}89 \\
59\end{array}$ & $\begin{array}{l}60.1 \\
39.9\end{array}$ & 4.3 & $0.038 * *$ \\
\hline $\begin{array}{c}\text { Tumor localization } \\
\text { - Unilateral } \\
\text { - } \text { bilateral }\end{array}$ & $\begin{array}{l}25 \\
3\end{array}$ & $\begin{array}{l}89.3 \\
10.7\end{array}$ & $\begin{array}{l}120 \\
0\end{array}$ & $\begin{array}{l}100 \\
0\end{array}$ & $\begin{array}{l}145 \\
3\end{array}$ & $\begin{array}{l}98 \\
2\end{array}$ & $13.6^{* *}$ & $0.006 * *$ \\
\hline $\begin{array}{l}\text { age at diagnosis in years } \\
\text { Mean } \pm \text { SD }\end{array}$ & 45. & \pm 7.9 & 50.8 & $=11.4$ & 49.5 & \pm 11 & 2.738 & $0.008 * *$ \\
\hline $\begin{array}{l}\text { age at menarche in years } \\
\text { Mean } \pm \text { SD }\end{array}$ & 12. & \pm 1.9 & 12.3 & \pm 2.3 & 12.3 & \pm 2.2 & 0.110 & 0.912 \\
\hline
\end{tabular}

FBC: familial breast cancer; SBC: sporadic breast cancer

*Fisher exact test

**statistically significant 
Table (3): Comparison between familial and sporadic breast cancer regarding pathological characteristics of breast cancer

\begin{tabular}{|c|c|c|c|c|c|c|c|c|}
\hline \multirow{2}{*}{$\begin{array}{l}\text { Pathological } \\
\text { characteristics }\end{array}$} & \multicolumn{2}{|l|}{ FBC } & \multicolumn{2}{|l|}{ SBC } & \multicolumn{2}{|l|}{ Total } & \multirow[t]{2}{*}{$\mathbf{X}^{2}$} & \multirow{2}{*}{$\mathbf{P}$} \\
\hline & $N=28$ & $\%$ & $\mathrm{~N}=120$ & $\%$ & $N=148$ & $\%$ & & \\
\hline $\begin{array}{l}\text { Histological type } \\
\text { - } \text { IDC } \\
\text { - ILC } \\
\text { - } \text { Mixed IDC\&ILC }\end{array}$ & $\begin{array}{l}25 \\
3 \\
0\end{array}$ & $\begin{array}{l}89.3 \\
10.7 \\
0\end{array}$ & $\begin{array}{l}108 \\
10 \\
2\end{array}$ & $\begin{array}{l}90 \\
8.3 \\
1.7\end{array}$ & $\begin{array}{l}133 \\
13 \\
2\end{array}$ & $\begin{array}{l}89.9 \\
8.8 \\
1.3\end{array}$ & 0.447 & 0.799 \\
\hline \begin{tabular}{cc}
\multicolumn{2}{l}{ Tumor size } \\
- $\mathrm{T} 1$ \\
- $\mathrm{T} 2$ \\
- $\mathrm{T} 3$ \\
- $\mathrm{T} 4$
\end{tabular} & $\begin{array}{l}3 \\
10 \\
8 \\
7\end{array}$ & $\begin{array}{l}10.7 \\
35.7 \\
28.6 \\
25\end{array}$ & $\begin{array}{l}13 \\
74 \\
30 \\
3\end{array}$ & $\begin{array}{l}10.8 \\
61.7 \\
25 \\
2.5\end{array}$ & $\begin{array}{l}16 \\
84 \\
38 \\
10\end{array}$ & $\begin{array}{l}10.9 \\
56.7 \\
25.7 \\
6.7\end{array}$ & 19.8 & $<0.001^{* *}$ \\
\hline $\begin{array}{l}\text { Estrogen receptors status } \\
\text { - ER+ } \\
\text { - } \text { ER- }\end{array}$ & $\begin{array}{l}23 \\
5\end{array}$ & $\begin{array}{l}82.1 \\
17.9\end{array}$ & $\begin{array}{l}106 \\
14\end{array}$ & $\begin{array}{l}88.3 \\
11.7\end{array}$ & $\begin{array}{l}129 \\
19\end{array}$ & $\begin{array}{l}87.2 \\
12.8\end{array}$ & $0.778^{*}$ & 0.378 \\
\hline $\begin{array}{l}\text { Progesterone receptors } \\
\text { status } \\
\text { - PR+ } \\
\text { - PR- }\end{array}$ & $\begin{array}{l}22 \\
6\end{array}$ & $\begin{array}{l}78.6 \\
21.4\end{array}$ & $\begin{array}{l}95 \\
25\end{array}$ & $\begin{array}{l}79.2 \\
20.8\end{array}$ & $\begin{array}{l}117 \\
31\end{array}$ & $\begin{array}{l}79 \\
21\end{array}$ & 0.005 & 0.944 \\
\hline $\begin{array}{l}\text { Her2 receptors status } \\
\text { - Her2+ } \\
\text { - Her2- }\end{array}$ & $\begin{array}{l}6 \\
22\end{array}$ & $\begin{array}{l}21.4 \\
78.6\end{array}$ & $\begin{array}{l}44 \\
76\end{array}$ & $\begin{array}{l}36.7 \\
63.3\end{array}$ & $\begin{array}{l}50 \\
98\end{array}$ & $\begin{array}{l}33.8 \\
66.2\end{array}$ & 2.3 & 0.125 \\
\hline $\begin{array}{l}\text { Triple negative } \mathrm{BC} \\
\text { - Yes } \\
\text { - } \mathrm{No}\end{array}$ & $\begin{array}{l}5 \\
23\end{array}$ & $\begin{array}{l}17.9 \\
82.1\end{array}$ & $\begin{array}{l}0 \\
120\end{array}$ & $\begin{array}{l}0 \\
100\end{array}$ & $\begin{array}{l}5 \\
143\end{array}$ & $\begin{array}{l}3.4 \\
96.6\end{array}$ & $23.1 *$ & $<0.001 * *$ \\
\hline
\end{tabular}

FBC: familial breast cancer; SBC: sporadic breast cancer; Her2: human epidermal growth factor 2 *Fisher exact test 